\title{
A CASE STUDY ON THE CONSOLIDATION OF FINANCIAL STATEMENTS OF ENTITIES AFFILIATED THROUGH DIRECT CONSOLIDATION PROCEDURE
}

\author{
Mihai Deju \\ "Vasile Alecsandri" University of Bacău \\ mihai.deju@ub.ro
}

\begin{abstract}
The preparation of annual consolidated financial statements, in the context of the existence of group companies, represents a relatively new problematic issue for accounting practitioners, the world of the academia, as well as for the regulating bodies in the field of accounting. This situation generates intense debates among accounting specialists with the aim of finding practical solutions that facilitate the understanding and correct application of accounting regulations in the area of consolidating accounts. The present article approaches, by means of a case study, the specific aspects related to the consolidation of affiliated entities' accounts by means of using the global integration method and the direct consolidation procedure.
\end{abstract}

\section{Keywords}

consolidation of accounts; consolidation procedures; global integration; direct consolidation

\section{JEL Classification}

M41

The drawing up of consolidated financial statements by means of the global integration method, irrespective of the employed procedure (consolidation on levels or direct consolidation) involves the cumulation of the items from the balance sheets and the profit and loss accounts of affiliated entities with the balance sheet items and the items of the profit and loss accounts of the parent company, as well as the making of the following adjustments:

- the division of the subsidiaries' equity capital elements between the quota the parent company is entitled to and the quotas for "other shareholders" of the subsidiaries as "interests of minority shareholders";

- the accounting recording, as elements of consolidated equity capitals, of the quotas from the equity elements of the subsidiaries that are allocated to the parent company;

- the separate accounting recording of the quota from the equities that are allocated to "other shareholders" of the subsidiaries as "interests of minority shareholders";

- the elimination of the equivalent value of shareholding titles owned by the parent company, directly or indirectly, from the consolidated subsidiaries and the diminishing of the equities of affiliated entities with an equivalent sum.

We will further present a case study regarding the consolidation of financial statements of affiliated entities by means of the direct consolidation procedure, starting from the hypothesis that the group is composed of four companies, as follows: the parent company A and the subsidiaries B, C and D. The parent company A owns $70 \%$ of the capital and voting rights of company B. Company B owns $80 \%$ of the capital and voting rights of company $\mathrm{C}$, and company $\mathrm{C}$ owns $90 \%$ of the capital and voting rights of company D. 
In this study, we considered that all shareholding titles owned in subsidiaries B, C and $\mathrm{D}$ represent ordinary shares and were purchased when the respective companies were established. The study does not present the particularities of accounting treatments corresponding to the reciprocal operations among the companies of the group because they can be the subject of other approaches.

Taking into account that the parent company has exclusive control over the subsidiaries, in order to carry out the consolidation of their financial statements we will employ the global integration method.

We will further present the individual financial statements of the group companies that will be the subject of consolidation, as follows:

a) Balance sheets of the companies that are part of the group:

\begin{tabular}{|c|c|c|c|c|}
\hline Items of balance sheets & $\begin{array}{c}\text { Company } \\
\mathbf{A}\end{array}$ & $\begin{array}{c}\text { Company } \\
\text { B }\end{array}$ & $\begin{array}{c}\text { Company } \\
\mathrm{C}\end{array}$ & $\begin{array}{c}\text { Company } \\
\text { D }\end{array}$ \\
\hline A. Fixed assets & 840,000 & 690,000 & 460,000 & 420,000 \\
\hline - Tangible fixed assets & 490,000 & 450,000 & 190,000 & 420,000 \\
\hline - shareholding titles & 350,000 & 240,000 & 270,000 & - \\
\hline $\begin{array}{l}\text { B. Current assets, } \\
\text { among which: }\end{array}$ & 570,000 & 340,000 & 320,000 & 220,000 \\
\hline - Stocks & 150,000 & 230,000 & 130,000 & 80,000 \\
\hline - Clients & 250,000 & 60,000 & 120,000 & 120,000 \\
\hline - Cash and bank accounts & 170,000 & 50,000 & 70,000 & 20,000 \\
\hline C. Advance expenses & - & - & - & - \\
\hline $\begin{array}{l}\text { D. Debts - sums that } \\
\text { should be paid within a } \\
\text { year }\end{array}$ & 190,000 & 150,000 & 160,000 & 130,000 \\
\hline - Suppliers & 65,000 & 70,000 & 65,000 & 50,000 \\
\hline - Various creditors & 125,000 & 80,000 & 95000 & 80,000 \\
\hline $\begin{array}{l}\text { E. Net current assets/ } \\
\text { Net current debts (B-D) }\end{array}$ & 380,000 & 190,000 & 160.000 & 90,000 \\
\hline $\begin{array}{l}\text { F. Total assets minus } \\
\text { current debts }\end{array}$ & $1,220,000$ & 880,000 & 620,000 & 510,000 \\
\hline $\begin{array}{l}\text { G. Debts - sums that } \\
\text { should be paid over a } \\
\text { period exceeding one } \\
\text { year }\end{array}$ & 50,000 & 60,000 & 50,000 & 40,000 \\
\hline H. Provisions & - & - & - & - \\
\hline I. Advance incomes & - & - & - & - \\
\hline J. Equity capitals & - & - & - & - \\
\hline - Subscribed capital & 850,000 & 500,000 & 300,000 & 300,000 \\
\hline - Capital premium & - & - & - & - \\
\hline $\begin{array}{lcc} & \text { Reserves } & \text { from } \\
\text { reevaluation } & \\
\end{array}$ & - & - & - & - \\
\hline - Reserves & 130,000 & 190,000 & 130,000 & 80,000 \\
\hline $\begin{array}{l}\text { - Profit or loss carried } \\
\text { forward }\end{array}$ & - & - & - & - \\
\hline $\begin{array}{lll}\text { Profit or loss of } \\
\text { financial year } & & \\
\end{array}$ & 190,000 & 130,000 & 140,000 & 90,000 \\
\hline TOTAL equity capitals & $1,170,000$ & 820,000 & 570,000 & 470,000 \\
\hline
\end{tabular}


b) Profit and loss accounts of companies within the group:

\begin{tabular}{|l|r|r|r|r|}
\hline \multicolumn{1}{|c|}{$\begin{array}{c}\text { Income and expense } \\
\text { items }\end{array}$} & $\begin{array}{c}\text { Company } \\
\text { A }\end{array}$ & $\begin{array}{c}\text { Company } \\
\text { B }\end{array}$ & $\begin{array}{c}\text { Company } \\
\text { C }\end{array}$ & $\begin{array}{c}\text { Company } \\
\text { D }\end{array}$ \\
\hline Operating income & $2,800,000$ & $1,300,000$ & $1,600,000$ & 900,000 \\
\hline Financial income & 200,000 & 150,000 & 230,000 & 150,000 \\
\hline Operating expenses & $2,600,000$ & $1,200.000$ & $1,450,000$ & 850,000 \\
\hline Financial expenses & 174,000 & 95,000 & 213,000 & 93,000 \\
\hline $\begin{array}{l}\text { Expenses with } \\
\text { corporation tax }\end{array}$ & 36,000 & 25,000 & 27,000 & 17,000 \\
\hline $\begin{array}{l}\text { Profit or loss of financial } \\
\text { year }\end{array}$ & 190,000 & 130,000 & 140,000 & 90,000 \\
\hline
\end{tabular}

In order to draw up the consolidated financial statements by means of the direct consolidation procedure, the following stages will be taken into account:

\section{STAGE 1}

The establishment of the shareholders' interest percentage of the parent company (of the group) in each subsidiary, as well as of the interests of minority shareholders:

\begin{tabular}{|l|c|c|c|}
\hline \multicolumn{1}{|c|}{ Indicators } & $\begin{array}{c}\text { Subsidiary } \\
\text { B }\end{array}$ & $\begin{array}{c}\text { Subsidiary } \\
\text { C }\end{array}$ & $\begin{array}{c}\text { Subsidiary } \\
\text { D }\end{array}$ \\
\hline Interest percentage of the parent company & $70 \%$ & $56 \%$ & $50,40 \%$ \\
\hline $\begin{array}{l}\text { Percentage of the interests of minority } \\
\text { shareholders }\end{array}$ & $30 \%$ & $44 \%$ & $49,60 \%$ \\
\hline
\end{tabular}

STAGE 2.

The cumulation of group companies' balance sheet items and their corresponding accounting recording:

2a. The table regarding the cumulation of the items of the balance sheets of the companies included in the consolidation area is presented below:

\begin{tabular}{|l|r|r|r|r|r|}
\hline $\begin{array}{l}\text { Items of balance } \\
\text { sheets }\end{array}$ & $\begin{array}{c}\text { Company } \\
\mathbf{A}\end{array}$ & $\begin{array}{c}\text { Company } \\
\text { B }\end{array}$ & $\begin{array}{c}\text { Company } \\
\text { C }\end{array}$ & $\begin{array}{c}\text { Company } \\
\text { D }\end{array}$ & $\begin{array}{c}\text { TOTAL } \\
\text { A+B+C+D }\end{array}$ \\
\hline A. Fixed assets & $\mathbf{8 4 0 , 0 0 0}$ & $\mathbf{6 9 0 , 0 0 0}$ & $\mathbf{4 6 0 , 0 0 0}$ & $\mathbf{4 2 0 , 0 0 0}$ & $\mathbf{2 , 4 1 0 , 0 0 0}$ \\
\hline $\begin{array}{l}\text { - tangible fixed } \\
\text { assets }\end{array}$ & 490,000 & 450,000 & 190,000 & 420,000 & $1,550,000$ \\
\hline - shareholding titles & 350,000 & 240,000 & 270,000 & - & 860,000 \\
\hline $\begin{array}{l}\text { B. Current assets, } \\
\text { among which: }\end{array}$ & $\mathbf{5 7 0 , 0 0 0}$ & $\mathbf{3 4 0 , 0 0 0}$ & $\mathbf{3 2 0 , 0 0 0}$ & $\mathbf{2 2 0 , 0 0 0}$ & $\mathbf{1 , 4 5 0 , 0 0 0}$ \\
\hline - Stocks & 150,000 & 230,000 & 130,000 & 80,000 & 590,000 \\
\hline - Clients & 250,000 & 60,000 & 120,000 & 120,000 & 550,000 \\
\hline $\begin{array}{l}\text {-Cash accounts } \\
\text { and bank accounts }\end{array}$ & 170,000 & 50,000 & 70,000 & 20,000 & 310,000 \\
\hline $\begin{array}{l}\text { C. Advance } \\
\text { expenses }\end{array}$ & - & - & & - & - \\
\hline $\begin{array}{l}\text { D. Debts - sums } \\
\text { that must be paid } \\
\text { within a year }\end{array}$ & $\mathbf{1 9 0 , 0 0 0}$ & $\mathbf{1 5 0 , 0 0 0}$ & $\mathbf{1 6 0 , 0 0 0}$ & $\mathbf{1 3 0 , 0 0 0}$ & $\mathbf{6 3 0 , 0 0 0}$ \\
\hline - Suppliers & 65,000 & 70,000 & 65,000 & 50,000 & 250,000 \\
\hline
\end{tabular}



DIRECT CONSOLIDATION PROCEDURE

\begin{tabular}{|l|r|r|r|r|r|}
\hline - Various creditors & 125,000 & 80,000 & 95,000 & 80,000 & 380,000 \\
\hline $\begin{array}{l}\text { E. Net current } \\
\text { assets/ Net current } \\
\text { debts (B-D) }\end{array}$ & $\mathbf{3 8 0 , 0 0 0}$ & $\mathbf{1 9 0 , 0 0 0}$ & $\mathbf{1 6 0 , 0 0 0}$ & $\mathbf{9 0 , 0 0 0}$ & $\mathbf{8 2 0 , 0 0 0}$ \\
\hline $\begin{array}{l}\text { F. Total assets } \\
\text { minus current } \\
\text { debts }\end{array}$ & $\mathbf{1 , 2 2 0 , 0 0 0}$ & $\mathbf{8 8 0 , 0 0 0}$ & $\mathbf{6 2 0 , 0 0 0}$ & $\mathbf{5 1 0 , 0 0 0}$ & $\mathbf{3 , 2 3 0 , 0 0 0}$ \\
\hline $\begin{array}{l}\text { G. Debts - sums } \\
\text { that should be paid } \\
\text { over a period } \\
\text { exceeding one year }\end{array}$ & $\mathbf{5 0 , 0 0 0}$ & $\mathbf{6 0 , 0 0 0}$ & $\mathbf{5 0 , 0 0 0}$ & $\mathbf{4 0 , 0 0 0}$ & $\mathbf{2 0 0 , 0 0 0}$ \\
\hline H. Provisions & - & - & - & - & - \\
\hline I. Advance incomes & - & - & - & - & - \\
\hline J. Equity capitals & - & - & - & - & - \\
\hline $\begin{array}{l}\text { - Subscribed } \\
\text { capital }\end{array}$ & 850,000 & 500,000 & 300,000 & 300,000 & $1,950,000$ \\
\hline - Capital premium & - & - & - & - & - \\
\hline $\begin{array}{l}\text { - Reserves from } \\
\text { reevaluation }\end{array}$ & - & - & - & - & - \\
\hline - Reserves & 130,000 & 190,000 & 130,000 & 80,000 & 530,000 \\
\hline $\begin{array}{l}\text { - Profit or loss } \\
\text { carried forward }\end{array}$ & - & - & - & - & - \\
\hline $\begin{array}{l}- \text { Profit or loss of } \\
\text { financial year }\end{array}$ & 190,000 & 130,000 & 140,000 & 90,000 & 550,000 \\
\hline $\begin{array}{l}\text { TOTAL equity } \\
\text { capitals }\end{array}$ & $\mathbf{1 , 1 7 0 , 0 0 0}$ & $\mathbf{8 2 0 , 0 0 0}$ & $\mathbf{5 7 0 , 0 0 0}$ & $\mathbf{4 7 0 , 0 0 0}$ & $\mathbf{3 , 0 3 0 , 0 0 0}$ \\
\hline
\end{tabular}

$2 b$. Accounting recording regarding the cumulation of group companies' balance sheet items (recording in the balance sheet):

\begin{tabular}{rlrrr}
$3,860,000$ & \multicolumn{1}{c}{$\%$} & \multicolumn{1}{c}{$\%$} & $3,860,000$ \\
$1,550,000$ & Fixed assets & & Share capital A & 850,000 \\
350,000 & Shareholding titles B & & Share capital B & 500,000 \\
240,000 & Shareholding titles C & & Share capital C & 300,000 \\
270,000 & Shareholding titles D & & Share capital D & 300,000 \\
590,000 & Stocks & & Reserves A & 130,000 \\
550,000 & Clients & & Reserves B & 190,000 \\
310,000 & Cash and bank & Reserves C & 130,000 \\
& accounts & Reserves D & 80,000 \\
& & Profit or loss A & 190,000 \\
& & Profit or loss B & 130,000 \\
& & Profit or loss C & 140,000 \\
& & Profit or loss D & 90,000 \\
& & Suppliers & 250,000 \\
& & & Various creditors & 380,000 \\
& & Long-term bank credits & 200,000
\end{tabular}

STAGE 3

Cumulation of profit and loss accounts of companies within the group and the making of corresponding adjustments: 
3a. The cumulation table of profit and loss items of the companies included in the consolidation area is presented below:

\begin{tabular}{|l|r|r|r|r|r|}
\hline \multicolumn{1}{|c|}{$\begin{array}{c}\text { Income and } \\
\text { expense items }\end{array}$} & $\begin{array}{c}\text { Company } \\
\text { A }\end{array}$ & $\begin{array}{c}\text { Company } \\
\text { B }\end{array}$ & $\begin{array}{c}\text { Company } \\
\text { C }\end{array}$ & $\begin{array}{c}\text { Company } \\
\text { D }\end{array}$ & $\begin{array}{c}\text { TOTAL } \\
\text { A+B+C+D }\end{array}$ \\
\hline Operating incomes & $2,800,000$ & $1,300,000$ & $1,600,000$ & 900,000 & $6,600,000$ \\
\hline Financial incomes & 200,000 & 150,000 & 230,000 & 150,000 & 730,000 \\
\hline Operating expenses & $2,600,000$ & $1,200,000$ & $1,450,000$ & 850,000 & $6,100,000$ \\
\hline Financial expenses & 174,000 & 95,000 & 213,000 & 93,000 & 575,000 \\
\hline $\begin{array}{l}\text { Expenses with } \\
\text { corporation tax }\end{array}$ & 36,000 & 25,000 & 27,000 & 17,000 & 105,000 \\
\hline $\begin{array}{l}\text { Profit or loss of } \\
\text { financial year }\end{array}$ & 190,000 & 130,000 & 140,000 & 90,000 & 550,000 \\
\hline
\end{tabular}

3b. Recording of the cumulation of profit and loss items of the companies within the group (recording in the profit and loss account) ${ }^{\mathbf{1}}$ :

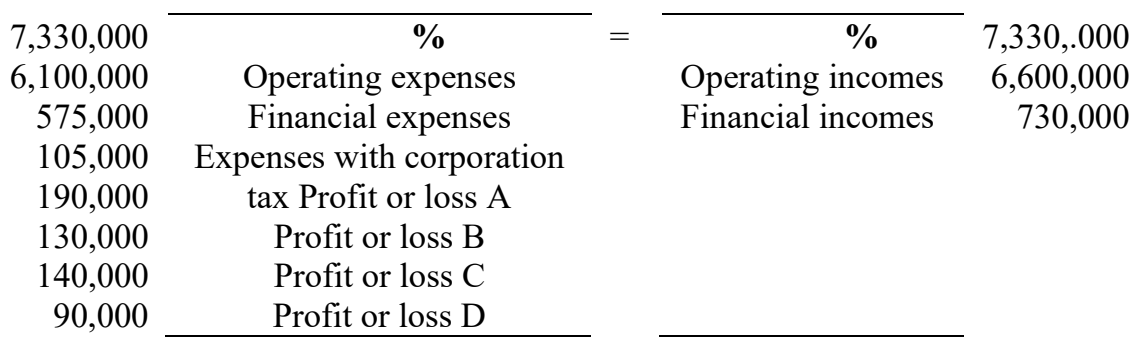

\section{STAGE 4.}

The division of the subsidiaries' equity capitals between the parent company and the minority interests (that do not have control) and the elimination of the equivalent value of the titles of the consolidated companies as well as their accounting recording

4.a. Table representing the division of equity capitals and the elimination of the equivalent value of the shareholding titles owned by Company A in Subsidiary B as a result of direct consolidation by parent company $A$

\begin{tabular}{|l|r|r|r|}
\hline \multicolumn{1}{|c|}{ Indicators } & $\begin{array}{c}\text { Total } \\
\text { subsidiary } \\
\mathbf{B}\end{array}$ & $\begin{array}{c}\text { Part } \\
\text { attributed to } \\
\text { group A } \\
\mathbf{( 7 0 \% )}\end{array}$ & $\begin{array}{c}\text { Part attributed to } \\
\text { interests of } \\
\text { minority } \\
\text { shareholders (30\%) }\end{array}$ \\
\hline 1. Share capital B & 500,000 & 350,000 & - \\
\hline $\begin{array}{l}\text { 2. Elimination of shareholding } \\
\text { titles (B) owned by company } \\
\text { A }\end{array}$ & $-350,000$ & $-350,000$ & 150,000 \\
\hline 3. Divided share capital (1-2) & 150,000 & & - \\
\hline 4. Reserves B & 190,000 & 133,000 & 150,000 \\
\hline 5. Profit or loss Subsidiary B & 130,000 & 91,000 & 57,000 \\
\hline TOTAL (3+4+5) & 470,000 & 224,000 & 24,000 \\
\hline
\end{tabular}

\footnotetext{
${ }^{1}$ Note: The cumulation of the income and expenses items is carried out at the level of the profit and loss account - a component of consolidated financial statements.
} 
4.a1. Accounting recording corresponding to the division of the subsidiaries' equity capitals, the elimination of the shareholding titles owned by Subsidiary B and the different representation of the interests of minority shareholders (recording at the level of the balance sheet):

\begin{tabular}{lcccr}
820,000 & $\mathbf{\%}$ & \multicolumn{1}{c}{$\mathbf{\%}$} & 820,000 \\
500,000 & Share capital B & & Shares owned in affiliated \\
190,000 & Reserves B & & entities (B) & 350,000 \\
130,000 & Profit or loss B & & Consolidated reserves & 133,000 \\
& & $\begin{array}{l}\text { Consolidated profit or loss } \\
\end{array}$ & $\begin{array}{r}\text { Interests of minority } \\
\text { shareholders }\end{array}$ & 246,000 \\
& & &
\end{tabular}

4.a2. Division of the financial result (profit/loss) in Subsidiary B (recording in the profit and loss account) ${ }^{2}$ :

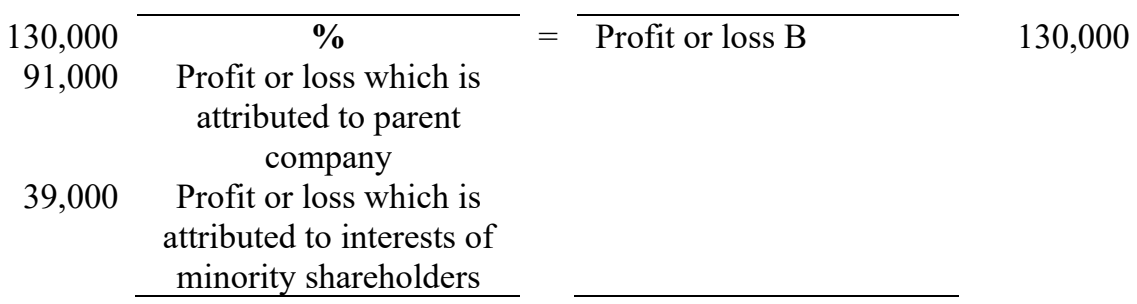

4.b. Table representing the division of equity capitals and the elimination of the equivalent value of the shareholding titles owned by Subsidiary B in Subsidiary C as a result of direct consolidation by parent company $\mathbf{A}$ :

\begin{tabular}{|l|r|r|r|}
\hline \multicolumn{1}{|c|}{ Indicators } & $\begin{array}{c}\text { Total } \\
\text { subsidiary } \\
\mathbf{C}\end{array}$ & $\begin{array}{c}\text { Part } \\
\text { attributed to } \\
\text { company A } \\
\mathbf{( 5 6 \% )}\end{array}$ & $\begin{array}{c}\text { Part attributed to } \\
\text { interests of minority } \\
\text { shareholders } \\
\mathbf{( 4 4 \% )}\end{array}$ \\
\hline 1. Share capital C & 300,000 & 168,000 & 132,000 \\
\hline $\begin{array}{l}\text { 2. Elimination of shareholding } \\
\text { titles (C) owned by company B } \\
(70 \%)^{*}\end{array}$ & 240,000 & $-168,000$ & $-72,000$ \\
\hline 3. Divided share capital (1-2) & 60,000 & $(240,000 \times 70 \%)$ & $(240,000 \times 30 \%)$ \\
\hline 4. Reserves C & 130,000 & - & 60,000 \\
\hline 5. Profit or loss of Subsidiary C & 140,000 & 78,800 & 57,200 \\
\hline TOTAL (3+4+5) & 330,000 & 151,200 & 61,600 \\
\hline
\end{tabular}

* The elimination of shareholding titles in subsidiary $\mathrm{C}$ is done on the basis of shareholders' interest percentage owned by the mother company in subsidiary B (70\%).

4.b1. Accounting recording corresponding to the division of the subsidiaries' equity capitals, the elimination of the shareholding titles owned by Subsidiary B in Subsidiary $\mathbf{C}$ and the different representation of the interests of minority shareholders (recording at the level of the balance sheet):

\footnotetext{
${ }^{2}$ The accounting recording is registered in the profit and loss account - a component of consolidated financial statements.
} 


\begin{tabular}{lclrr}
570,000 & $\mathbf{\%}$ & \multicolumn{1}{c}{$\%$} & 570,000 \\
300,000 & Share capital C & & Shares owned in affiliated & \\
130,000 & Reserves C & & entities (B) & 240,000 \\
140,000 & Profit or loss C & & Consolidated reserves & 72,800 \\
& & Consolidated profit or loss & 78,400 \\
& & & 178,800 \\
& & Interests of minority & shareholders & \\
& &
\end{tabular}

4.b2. Division of the financial result (profit/loss) of Subsidiary $\mathbf{C}$ (recording in the profit and loss account - a component of financial statements):

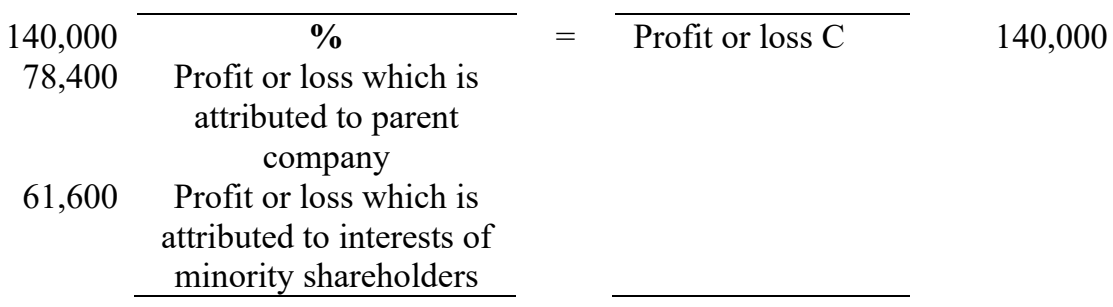

4.c. Table representing the division of equity capitals and the elimination of the equivalent value of the shareholding titles owned by Subsidiary $C$ in Subsidiary $D$ as a result of direct consolidation by parent company $A$ :

\begin{tabular}{|l|r|r|r|}
\hline \multicolumn{1}{|c|}{ Indicators } & Total D & \multicolumn{1}{|c|}{$\begin{array}{c}\text { Part } \\
\text { attributed to } \\
\text { company A } \\
\mathbf{( 5 0 , 4 0 \% )}\end{array}$} & $\begin{array}{c}\text { Part attributed to } \\
\text { interests of minority } \\
\text { shareholders } \\
\mathbf{( 4 9 , 6 0 \% )}\end{array}$ \\
\hline 1. Share capital D & 300,000 & 151,200 & 148,800 \\
\hline $\begin{array}{l}\text { 2. Elimination of shareholding } \\
\text { titles (D) owned by company } \\
\text { C (56\%)* }\end{array}$ & 270,000 & 151,200 & 118,800 \\
\hline 3. Divided share capital (1-2) & 30,000 & $(270,000 \times 56 \%)$ & $(270,000 \times 56 \%)$ \\
\hline 4. Reserves D & 80,000 & 40,320 & 30,000 \\
\hline 5. Profit or loss D & 90,000 & 45,360 & 39,680 \\
\hline TOTAL (3+4+5) & 200,000 & 85,680 & 114,320 \\
\hline
\end{tabular}

*The elimination of shareholding titles in subsidiary D is performed on the basis of shareholders' interest percentage owned by the mother company in subsidiary C (56\%).

4.c1. Accounting recording corresponding to the division of the subsidiaries' equity capitals, the elimination of the shareholding titles owned by Subsidiary $C$ in Subsidiary $D$ and the different representation of the interests of minority shareholders (recording at the level of the balance sheet):

\begin{tabular}{rccr}
\cline { 2 - 2 } 470,000 & $\mathbf{\%}$ & $\mathbf{\%}$ & 470,000 \\
300,000 & Share capital D & & Shares owned at affiliated \\
80,000 & Reserves D & entities D & 270,000 \\
90,000 & Profit or loss D & Consolidated reserves & 40,320 \\
& & & Consolidated profit or loss \\
& & Interests of minority & 45,360 \\
& & shareholders & 114,320 \\
& & &
\end{tabular}

4.c2. Division of the financial result (profit/loss) of Subsidiary D (recording in the profit and loss account - a component of financial statements): 


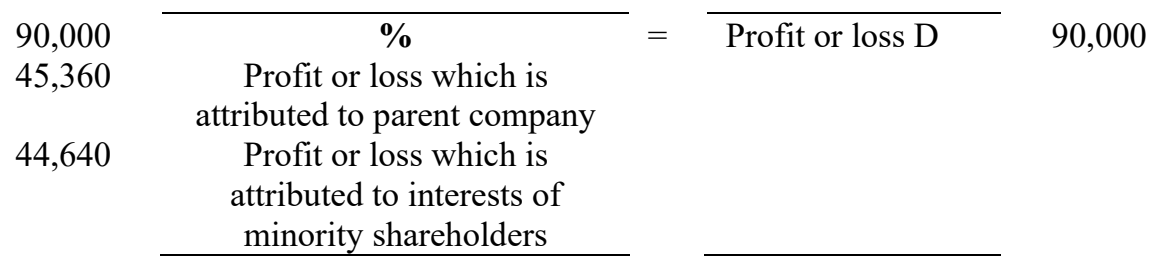

4.c.3. The transfer of equity capitals' elements (reserves and profit or loss - in our case) of the parent company to the reserves and the consolidated financial result of Group A (recording at the level of the balance sheet):

\begin{tabular}{|c|c|c|}
\hline 320,000 & $\%$ & $\%$ \\
\hline & Reserves A & Consolidated reserves \\
\hline 90,000 & Profit or loss A & Consolidated profit or loss \\
\hline
\end{tabular}

\section{STAGE 5}

5.a. The drawing up of the Register corresponding to the consolidation operations of the balance sheet items carried out in stages 1-4:

\begin{tabular}{|c|c|c|c|c|}
\hline \multirow[t]{2}{*}{ Items of balance sheets } & \multirow{2}{*}{$\begin{array}{c}\text { Cumulated } \\
\text { balance } \\
\text { sheet items } \\
\mathbf{A}+\mathbf{B}+\mathbf{C}+\mathbf{D}\end{array}$} & \multicolumn{2}{|c|}{$\begin{array}{l}\text { Restatements } \\
\text { corresponding to } \\
\text { consolidation }\end{array}$} & \multirow{2}{*}{$\begin{array}{c}\text { Consolidated } \\
\text { balance sheet } \\
\text { items } \\
\text { (Group A) }\end{array}$} \\
\hline & & Debit & Credit & \\
\hline 1. Fixed assets & $1,550,000$ & - & - & $1,550,000$ \\
\hline 2. Shareholding titles B & 350,000 & - & 350,000 & - \\
\hline 3. Shareholding titles $\mathrm{C}$ & 240,000 & - & 240,000 & - \\
\hline 4. Shareholding titles D & 270,000 & - & 270,000 & - \\
\hline 5. Stocks & 590,000 & - & - & 590,000 \\
\hline 6. Clients & 550,000 & - & - & 550,000 \\
\hline $\begin{array}{l}\text { 7. Cash and bank } \\
\text { accounts }\end{array}$ & 310,000 & - & - & 310,000 \\
\hline TOTAL ASSETS & $3,860,000$ & - & - & $3,000,000$ \\
\hline 8. Share capital A & 850,000 & - & - & 850,000 \\
\hline 9. Share capital B & 500,000 & 500,000 & - & - \\
\hline 10. Share capital C & 300,000 & 300,000 & - & - \\
\hline 11. Share capital D & 300,000 & 300,000 & - & - \\
\hline 12. Reserves A & 130,000 & 130,000 & - & - \\
\hline 13. Reserves B & 190,000 & 190,000 & - & - \\
\hline 14. Reserves C & 130,000 & 130,000 & - & - \\
\hline 15. Reserves D & 80,000 & 80,000 & - & \\
\hline $\begin{array}{l}\text { 16. Consolidated } \\
\text { reserves }\end{array}$ & - & - & $\begin{array}{r}133,000 \\
72,800 \\
40,320 \\
130,000 \\
\end{array}$ & 376,120 \\
\hline 17. Profit or loss A & 190,000 & 190,000 & - & - \\
\hline 18. Profit or loss B & 130,000 & 130,000 & - & - \\
\hline 19. Profit or loss $C$ & 140,000 & 140,000 & - & - \\
\hline 20. Profit or loss D & 90,000 & 90,000 & - & - \\
\hline $\begin{array}{l}\text { 21. Consolidated profit } \\
\text { or loss }\end{array}$ & & & $\begin{array}{l}91,000 \\
78,400 \\
45,360\end{array}$ & 404,760 \\
\hline
\end{tabular}




\begin{tabular}{|c|c|c|c|c|}
\hline & & & 190,000 & \\
\hline $\begin{array}{l}\text { 22. Interests of minority } \\
\text { shareholders }\end{array}$ & - & - & $\begin{array}{l}246,000 \\
178,800 \\
114,320\end{array}$ & 539,120 \\
\hline 23. Suppliers & 250,000 & - & - & 250,000 \\
\hline 24. Various creditors & 380,000 & - & - & 380,000 \\
\hline 25. Long-term credit & 200,000 & - & - & 200,000 \\
\hline $\begin{array}{l}\text { 26. TOTAL } \\
\text { LIABILITIES }\end{array}$ & $3,860,000$ & & & $3,000,000$ \\
\hline 27. Total sums $\mathrm{D} / \mathrm{C}$ & & $2,180,000$ & $2,180,000$ & \\
\hline
\end{tabular}

5.b. The drawing up of the Register corresponding to the consolidation operations of the profit or loss account carried out in stages 1-4:

\begin{tabular}{|c|c|c|c|c|}
\hline \multirow[t]{2}{*}{ Income and expense items } & \multirow[t]{2}{*}{$\begin{array}{c}\text { Cumulated } \\
\text { incomes } \\
\text { and } \\
\text { expenses } \\
A+B+C+D\end{array}$} & \multicolumn{2}{|c|}{\begin{tabular}{|c|} 
Division of results \\
between Group A and \\
interests of minority \\
shareholders \\
\end{tabular}} & \multirow[t]{2}{*}{$\begin{array}{c}\text { Consolidated } \\
\text { incomes and } \\
\text { expenses } \\
\text { (Group A) }\end{array}$} \\
\hline & & Debit & Credit & \\
\hline Operating incomes & $6,600,000$ & - & - & $6,600,000$ \\
\hline Financial incomes & 730,000 & - & - & 730,000 \\
\hline Operating expenses & $6,100,000$ & - & - & $6,100,000$ \\
\hline Financial expenses & 575,000 & - & - & 575,000 \\
\hline Expenses with corporation tax & 105,000 & - & - & 105,000 \\
\hline $\begin{array}{l}\text { Profit or loss of financial } \\
\text { year, among which: }\end{array}$ & 550,000 & 550,000 & - & \\
\hline Profit or loss $A$ & 190,000 & 190,000 & - & - \\
\hline Profit or loss $B$ & 130,000 & 130,000 & - & \\
\hline Profit or loss $C$ & 140,000 & 140,000 & - & - \\
\hline Profit or loss D & 90,000 & 90,000 & - & \\
\hline $\begin{array}{l}\text { Profit or loss corresponding } \\
\text { to parent company (Group } \\
\text { A) }\end{array}$ & & & $\begin{array}{r}91,000 \\
78,400 \\
45,360 \\
190,000\end{array}$ & 404,760 \\
\hline $\begin{array}{l}\text { Profit or loss corresponding } \\
\text { to the interests of minority } \\
\text { shareholders }\end{array}$ & & & $\begin{array}{l}39,000 \\
61,600 \\
44,640\end{array}$ & 145,240 \\
\hline TOTAL & & 550,000 & 550,000 & \\
\hline
\end{tabular}

STAGE 6

After completing the first 5 stages, the parent company prepares the consolidated financial statements, namely, the consolidated balance sheet and the consolidated profit and loss account of group $\mathrm{A}$.

\section{A. Consolidated balance sheet GROUP A}

\begin{tabular}{|l|r|}
\hline \multicolumn{1}{|c|}{ Items of balance sheets } & \multicolumn{1}{c|}{$\begin{array}{c}\text { Group of } \\
\text { companies }\end{array}$} \\
\hline A. Fixed assets & $\mathbf{1 , 5 5 0 , 0 0 0}$ \\
\hline B. Current assets & $\mathbf{1 , 4 5 0 , 0 0 0}$ \\
\hline -Stocks & 590,000 \\
\hline -Clients & 550,000 \\
\hline
\end{tabular}




\begin{tabular}{|l|r|}
\hline \multicolumn{1}{|c|}{-Cash and bank accounts } & 310,000 \\
\hline C. Advance expenses & $\mathbf{6 3 0 , 0 0 0}$ \\
\hline $\begin{array}{l}\text { D. Current debts - sums that must be paid in less than a } \\
\text { year }\end{array}$ & 250,000 \\
\hline -Suppliers & 380,000 \\
\hline -Various creditors & $\mathbf{8 2 0 , 0 0 0}$ \\
\hline E. Net current assets/ Net current debts (B-D) & $\mathbf{2 , 3 7 0 , 0 0 0}$ \\
\hline F. Total assets minus current debts (A+B-D) & $\mathbf{2 0 0 , 0 0 0}$ \\
\hline $\begin{array}{l}\text { G. Debts - sums that should be paid over a period exceeding } \\
\text { one year }\end{array}$ & - \\
\hline H. Provisions & - \\
\hline I. Advance incomes & $\mathbf{8 5 0 , 0 0 0}$ \\
\hline J. Equity capitals & - \\
\hline 1. Share capital & - \\
\hline 2. Capital premium & 376,120 \\
\hline 3. Reserves from reevaluation & - \\
\hline 4. Consolidated reserves (133.000+72.800+40.320+130.000) & 404,760 \\
\hline 5. Profit or loss carried forward & $\mathbf{5 3 9 , 1 2 0}$ \\
\hline $\begin{array}{l}\text { 6. Consolidated profit or loss of the financial year } \\
\text { (91.000+78.400+45.360+190.000) }\end{array}$ & \\
\hline $\begin{array}{l}\text { Interests of minority shareholders } \\
\text { (246.000+178.800+114.320) }\end{array}$ & $\mathbf{2 , 1 7 0 , 0 0 0}$ \\
\hline \multicolumn{1}{|c|}{ Total equity capitals } & \\
\hline
\end{tabular}

\section{B. Consolidated profit and loss account GROUP A}

\begin{tabular}{|l|r|}
\hline \multicolumn{1}{|c|}{ Indicators } & Group of companies \\
\hline Operating incomes & $6,600,000$ \\
\hline Financial incomes & 730,000 \\
\hline Operating expenses & $6,100,000$ \\
\hline Financial expenses & 575,000 \\
\hline Expenses on corporation tax & 105,000 \\
\hline Profit or loss of the financial year, including & 550,000 \\
- the part attributed to shareholders in the parent company & 404,760 \\
\hline - part attributed to interests of minority shareholders & 145,240 \\
\hline
\end{tabular}

\section{Conclusions}

The simple consultation of the individual financial statements of the companies that are part of the consolidation area of a group, presented cumulatively, does not allow us to create a real picture of the economic-financial situation of the group, taking into account that the reciprocal operations among the companies that are part of the group are not recorded and nor are their consequences. At the same time, the cumulated individual accounts do not provide a truthful image of equity capitals, including the financial results that belong to the shareholders of the parent company, as distinct from the part that is attributed to other "other shareholders" as "interests of minority shareholders" (shareholders of other companies than the parent company or its affiliated entities).

The necessity of approaching, by means of a case study, the applicative nature regarding the use of the direct consolidation procedure for the individual financial statements of companies that form a group seems all the more imperative given that the accounting theory and practice do not abound in effective solutions for the application of accounting regulations concerning the preparation of consolidated financial 
statements. This is why we consider that our study can represent a useful guide for accounting practitioners as well as for students in economics that study accounting.

Confident that the accounting theory and practice can be permanently improved, I am eager to receive proposals or suggestions regarding the problematics approached in the current article.

\section{References}

Bogdan, V., Fărcane, N., Popa, D.N., Boloş, M.I. (2011), Raportarea financiară la nivelul grupurilor de societăți - Repere contemporane, București, Editura Economică.

Deju, M. (2019), Note de curs Contabilitate consolidată - Bacău.

Feleagă, N., Feleagă, L. (2007), Contabilitate consolidată. O abordare europeană și internațională, București, Editura Economică.

OMPF no. 1802/2014 for the approval of Accounting Standards concerning annual individual financial statements and annual consolidated financial statements, with subsequent amendments and additions. 